\title{
MANAJEMEN KELUHAN PELANGGAN PERUSAHAAN DAERAH AIR MINUM TIRTA SATRIA KABUPATEN BANYUMAS
}

\section{CUSTOMER COMPLAINT MANAGEMENT OF TIRTA SATRIA LOCAL WATER COMPANY OF BANYUMAS REGENCY}

\author{
Thahrina Azriah, Paulus Israwan Setyoko, Bambang Tri Harsanto \\ Program Magister Ilmu Administrasi, Fakultas Ilmu Sosial dan Ilmu Politik \\ Universitas Jenderal Soedirman \\ thahrina.azriah@gmail.com
}

\begin{abstract}
Abstrak
Penelitian ini dilatarbelakangi oleh hasil survei pada situs PDAM Tirta Satria, yang menunjukkan 508 pelanggan atau 74,5\% menyatakan pelayanan masih belum maksimal. Selain itu, terdapat 1506 keluhan hingga bulan Juli 2017. Oleh karena itu, perlu adanya penelitian mengenai manajemen keluhan pelanggan PDAM Tirta Satria beserta aspek-aspek yang mempengaruhinya. Tujuan penelitian adalah untuk mendeskripsikan manajemen keluhan PDAM Tirta Satria, dan mengidentifikasi aspek-aspek yang mempengaruhinya. Penelitian menggunakan metode penelitian kualitatif. Teknik pemilihan informan menggunakan teknik purposive sampling. Metode pengumpulan data menggunakan wawancara, observasi, dan dokumentasi. Hasil penelitian menunjukkan manajemen keluhan PDAM Tirta Satria belum terlaksana secara maksimal berdasarkan teori Stauss dan Seidel. Sebagian pelanggan belum mengetahui informasi layanan Call Center dan media penyampaian keluhan lainnya. Standar operasi prosedur penanganan keluhan belum memiliki batas waktu maksimal yang jelas. Jumlah pegawai teknis terbatas sehingga terkadang sulit menangani banyak keluhan secara bersamaan. Survei kepuasan pelanggan atas penanganan keluhan belum terlaksana. Sementara itu, aspek-aspek yang mempengaruhi manajemen keluhan PDAM Tirta Satria adalah aspek sumber daya manusia, organisasional, dan teknologi informasi.
\end{abstract}

Kata kunci: keluhan, manajemen keluhan, pelanggan.

\begin{abstract}
This research was based on the survey result on Tirta Satria Local Water Company's (LWC) website, it indicated that 508 or $74,5 \%$ customers stated that the service has not been maximum. Meanwhile, there were 1506 complaints reported until July, 2017. Therefore, it was necessary to conduct a research on complaints management of Tirta Satria LWC customers and its affecting aspects. The purposes of this research were to describe the complaint management of Tirta Satria LWC, and to identify its affecting aspects. This research used qualitative research method. Purposive sampling technique was used to select informants. Methods of data collection used interview, observation, and documentation. The result showed that complaint management in Tirta Satria has not been maximum based on Stauss and Seidel's complaint management theory. Some costumers did
\end{abstract}


not aware of Call Center service information and other complaint media. The standard operational procedure of complaint handling did not have clear deadline. The number of tehnician was limited, so that it was difficult to handle multiple complaints simultaneously. Customer satisfaction survey on complaint handling has not been implemented. On the other hand, the aspects affecting complaint management of Tirta Satria LWC were human resources, organizational, and information technology aspects.

\section{Keywords: complaint, complaint management, customer.}

\section{A. Pendahuluan}

Keluhan umumnya timbul karena adanya ketidakpuasan atas produk maupun jasa (Brennan dan Douglas, 2002; Hsiao et al, 2016). Keluhan muncul ketika pelangan mengalami kegagalan layanan publik seperti tidak memenuhi harapan, perlakuan yang tidak pantas/tidak sopan, tidak sesuai norma, janji yang tidak terpenuhi, kelalaian, kealpaan, kesalahan, ketidakkonsistenan, bimbingan yang menyesatkan, prosedur yang tidak jelas, adanya bias atau ketidakadilan yang ditunjukkan ketika mereka berhubungan dengan pejabat publik (Brewer, 2007; Nimako, 2012; Ryngelblum, 2013; Walle, 2016). Keluhan dapat dinyatakan secara verbal dan non verbal (Lovelock dan Wirtz, 2011; Tronvoll, 2011; Vuk, 2013). Keluhan pelanggan dianggap penting karena mengandung informasi mengenai berbagai masalah dalam proses pelayanan publik sehingga dapat membantu lembaga penyedia layanan publik untuk menyelesaikannya dan mengembalikan kepuasan dan kepercayaan pelanggan (Tojib dan Khazade, 2014; Filip 2013, Ogbeide 2015).

Manajemen keluhan merupakan cara perusahaan dalam mengumpulkan, menyelesaikan, merespon, memperbaiki layanan kemudian mencegah keluhan pelanggan tentang permasalahan pelayanan yang kurang memuaskan (Johnston, 2001; Alvarez et al, 2011; Taleghani et al, 2011, Ogbeide et al, 2015). Manajemen keluhan dapat dilihat sebagai sistem input-output, dimana keluhan pelanggan sebagai input, dan respon terhadap pelanggan sebagai output dalam suatu lingkungan (Vos, 2008). Staus dan Seidel (2010) menyatakan proses manajemen keluhan berawal dari manajemen keluhan secara langsung atau direct complaint management process (terdiri dari tahap stimulasi keluhan, penerimaan keluhan, pemrosesan keluhan, reaksi atas keluhan), dan dilanjutkan manajemen keluhan secara tidak langsung atau indirect complaint management process (terdiri dari tahap analisis keluhan, pengendalian manajemen keluhan, pelaporan keluhan, pemanfaatan informasi keluhan).
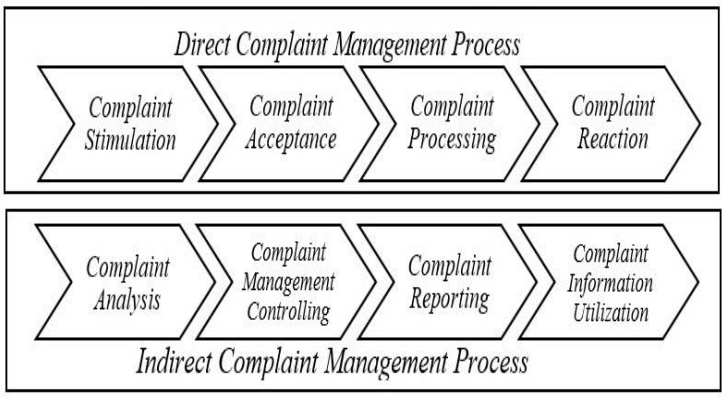

Gambar 1. Teori Manajemen Keluhan Sumber: Stauss dan Seidel (2010: 417) 
Salah satu contoh pelayanan publik yang tidak bisa menghindari keluhan pelanggan adalah PDAM Tirta Satria Kabupaten Banyumas. Hasil polling di https://pdambanyumas.com menunjukkan sebagian besar pelanggan yaitu $74,5 \%$ atau 508 orang menyatakan kualitas pelayanan air bersih masih kurang baik (dapat dilihat pada tabel 1). Persepsi tersebut pun dijelaskan dengan fenomena tingginya keluhan pelanggan hingga bulan Juli 2017 sejumlah 1506 keluhan (dapat dilihat pada tabel 2).

Tabel 1. Polling Kualitas Layanan

PDAM Tirta Satria Banyumas

\begin{tabular}{cccc}
\hline No. & Tingkat kualitas pelayanan & Jumlah suara & Persentase \\
\hline 1. & Kurang & 508 & $74,5 \%$ \\
\hline 2. & Baik & 98 & $14,4 \%$ \\
\hline 3. & Sedang & 60 & $8,8 \%$ \\
\hline 4. & Pertahankan & 11 & $1,0 \%$ \\
\hline Total & & 677 & $100 \%$ \\
\hline
\end{tabular}

Sumber:https://pdambanyumas.com/i ndex.php/component/poll/14-bagaimana-layanan-pdam-saatini

Tabel 2. Total Keluhan Pelanggan

PDAM Tirta Satria Kabupaten

Banyumas Hingga Bulan Juli 2017

\begin{tabular}{llccc}
\hline No. & \multicolumn{1}{c}{ Uraian } & $\begin{array}{c}\text { Total Keluhan Hingag } \\
\text { Bulan Juli 2017 }\end{array}$ & $\begin{array}{c}\text { Selesai } \\
\text { dilaksanakan }\end{array}$ & Persentase \\
\hline 1. & Angka Meter tidak sesuai & 2 & 2 & $0,13 \%$ \\
\hline 2. & Lonjakan pemakaian & 111 & 111 & $7,37 \%$ \\
\hline 3. & Bocor & 651 & 651 & $43,23 \%$ \\
\hline 4. & Air mati & 376 & 376 & $24,97 \%$ \\
\hline 5. & Air kecil tidak lancar & 149 & 149 & $9,89 \%$ \\
\hline 6. & Air keruh & 56 & 56 & $3,71 \%$ \\
\hline 7. & Meteran rusak & 39 & 39 & $2,59 \%$ \\
\hline 8. & Kerusakan Acc & 79 & 79 & $5,24 \%$ \\
\hline 9. & Pindah meter & 7 & 7 & $0,46 \%$ \\
\hline 10. & Galian pipa & 4 & 4 & $0,26 \%$ \\
\hline 11. & Lain-lain & 32 & 32 & $2,12 \%$ \\
\hline & Jumlah & 1506 & 1506 & $100 \%$ \\
\hline
\end{tabular}

Sumber: Dokumentasi PDAM Tirta Satria Kabupaten Banyumas
PDAM Tirta Satria telah memiliki Standar Operasi Prosedur (SOP) Pelayanan Pengaduan Pelanggan yang berisikan prosedur maupun tugas-tugas dari unit organisasi terkait dalam menangani keluhan pelanggan, namun SOP tersebut belum memiliki batas waktu penanganan maksimal, masih bersifat "segera'. Hal ini berpotensi pada penanganan keluhan yang tidak memberikan kepastian waktu kepada pelanggan, dan dapat meningkatkan ketidakpuasan pelanggan. Oleh karena itu, perlu adanya penelitian mengenai bagaimana proses pelaksanaan manajemen keluhan PDAM Tirta dilaksanakan, beserta aspek-aspek yang dapat mempengaruhi pelaksanaan manajemen keluhan tersebut.

Maka, rumusan masalah dalam penelitan ini adalah "Bagaimanakah manajemen keluhan pelanggan PDAM Tirta Satria Kabupaten Banyumas berdasarkan teori manajemen keluhan?", dan "Aspekaspek apa saja yang mempengaruhi manajemen keluhan PDAM Tirta Satria?". Tujuan yang ingin dicapai dalam penelitian ini adalah untuk mendeskripsikan manajemen keluhan PDAM Tirta Satria, serta mengidentifikasi aspek-aspek yang mempengaruhi pelaksanaan manajemen keluhan PDAM Tirta.

\section{B. Metode Penelitian}

Penelitian dilakukan di PDAM Tirta Satria Kabupaten Banyumas. Metode penelitian yang digunakan adalah metode penelitian kualitatif. Teknik pemilihan informan yang digunakan adalah purposive sampling dan accidental sampling. Sasaran penelitian penelitian ini adalah pihak-pihak yang berkaitan 
dalam proses penanganan keluhan pelanggan PDAM Tirta Satria Kabupaten Banyumas yaitu Kasubbag Pelayanan, Staf Bagian Pusat Pelayanan, Staf Bagian Teknik, Kasubbag Umum, dan masyarakat yang pernah mengajukan keluhan. Teknik pengumpulan data pun dilakukan melalui wawancara, observasi, dan dokumentasi. Sementara itu, teknik analisis data yang digunakan adalah model Miles et al. (2014) yang terdiri dari data collection, data condensation, data display, and conclusion/ drawing/ verification. Uji validitas penelitian ini menggunakan teknik triangulasi sumber data.

\section{Pembahasan}

\section{Proses Manajemen Keluhan} Secara Langsung (Direct Complaint Management Process)

Manajemen keluhan diawali dengan adanya proses manajemen keluhan secara langsung. Menurut Stauss dan Seidel (2010), manajemen keluhan secara langsung merupakan proses yang terjadi pada saat adanya kontak antara pelanggan dan petugas layanan suatu lembaga. Manajemen keluhan secara langsung terdiri dari beberapa tahap, yaitu sebagai berikut.

\section{a. Stimulasi Keluhan (Complaint Stimulation)}

Berry et al. (2015) menyatakan pelanggan yang merasa tidak puas akan menyampaikan keluhan secara langsung melalui media sosial, review secara online, atau pun menjelek-jelekkan (negative word of mouth). Oleh karena itu perlu stimulasi dari penyedia layanan agar para pelanggan dapat menyuarakan ketidakpuasannya secara langsung. Stauss dan Seidel (2010) menyatakan bahwa stimulasi keluhan dapat dilakukan dengan memberikan stimulasi untuk menyampaikan keluhan secara tertulis, dan menyediakan kontak telepon. PDAM Tirta Satria pun telah menyediakan kolom komentar atau keluhan pelanggan di situs https://pdambanyumas.com/ yang dapat diakses 24 jam, dan beserta layanan Call Center di (0281) 632324.

Selain itu, Stauss dan Seidel (2010) menjelaskan bahwa seluruh informasi tentang media stimulasi keluhan pelanggan tersebut harus secara aktif diiklankan dan dikomunikasikan ke pelanggan. PDAM Tirta Satria pun telah berusaha menginformasikan dan mengiklankan layanan pengaduan keluhan melalui berbagai cara, seperti mencantumkan informasi nomor Call Center dan alamat kantor di rekening tagihan air yang dimiliki setiap pelanggan, di koran, di situs https://pdambanyumas.com/, dan di kalender yang di produksi oleh PDAM Tirta Satria. Sayangnya, informan dari sisi pelanggan kurang menyadari dan kurang memperhatikan adanya informasi tersebut (seperti informasi kontak di rekening tagihan). Sehingga para informan dari sisi pelanggan lebih memilih untuk datang langsung ke kantor saat mengajukan keluhan, tidak dengan cara menelepon atau menuliskan komentar di situs PDAM Tirta Satria.

\section{Proposisi 1 :}

Beberapa pelanggan yang tidak menyadari informasi tentang beragam cara penyampaian keluhan, akan cenderung menggunakan satu jenis cara dalam menyampaikan keluhan. 
b. Penerimaan Keluhan (Complaint Acceptance)

Tahap penerimaan keluhan berkaitan dengan mengorganisasikan input berupa keluhan pelanggan yang baru saja diterima dan proses pendokumentasiannya informasi dari keluhan (Stauss dan Seidel, 2010). Tahap peneriman keluhan di PDAM Tirta diawali dengan menerima keluhan pelanggan melalui berbagai cara seperti layanan telepon, kolom komentar pelanggan di situs https://pdambanyumas.com/, maupun laporan langsung para pelanggan yang datang langsung ke kantor PDAM Tirta Satria setiap harinya. Para pegawai dan pelanggan mengkonfirmasi bahwa prosedur penyampaian keluhan mudah untuk dilakukan.

Sistem pengelolaan keluhan dapat dibantu perangkat lunak bila dihadapkan dengan jumlah keluhan yang tinggi, dan harus mendokumentasikan seluruh informasi relevan dari keluhan secara keseluruhan, cepat, dan terstruktur (Stauss dan Seidel, 2010). PDAM Tirta Satria menggunakan sistem dokumentasi berbasis elektronik yaitu SIKOMPAK, yang menghubungkan unit organisasi terkait dalam pelayanan pengaduan keluhan pelanggan (seperti Pusat Pelayanan, Kasubbag Pelayanan, Kasubbag Umum, dan Bagian Teknik). SIKOMPAK akan mendokumentasikan dan menyebarkan informasi identitas pelanggan (seperti nama dan nomor ID pelanggan), jenis keluhan (masalah atau hambatan yang dialami pelanggan dalam pelayanan air bersih), dan alamat dari pelanggan ke unit terkait sehingga arus informasi keluhan berjalan lancar.

\section{Proposisi 2:}

Kemudahan akses penyampaian keluhan beserta sistem dokumentasi terintegrasi dan berbasis elektronik dapat mendukung kelancaran tahap penerimaan keluhan lembaga pelayanan publik.

c. Pemrosesan Keluhan (Complaint Processing)

Pemrosesan keluhan berkaitan dengan pengorganisasian prosedur pengolahan keluhan secara internal, penentuan tanggung jawab dan batas waktu yang jelas, serta adanya mekanisme pengawasan (Stauss dan Seidel, 2010). Hasil penelitian menunjukkan PDAM Tirta Satria telah memiliki SOP Pelayanan Pengaduan Pelanggan yang memuat secara jelas tanggung jawab dari setiap unit organisasi terkait. Prosedur dari SOP secara singkat adalah dimulai dari penerimaan keluhan pelanggan oleh bagian Pusat Pelayanan yang kemudian didokumentasikan melalui sistem SIKOMPAK maupun Nota Pengaduan. Informasi tentang keluhan tersebut disebarkan ke unit terkait, seperti tim teknik dan Kasubag Umum. Jika tim teknik membutuhkan barang untuk proses perbaikan, maka dapat mengajukan Bon Bahan ke Kasubbag Umum. Setelah mendapatkan persetujuan beserta barangnya, tim teknik akan turun ke lapangan menangani keluhan pelanggan. 
Namun, proses penyelesaian keluhan pelanggan dalam SOP tersebut masih belum maksimal. Hal ini dikarenakan PDAM Tirta Satria belum mencantumkan batas waktu maksimal dalam penanganan keluhan pelanggan, masih bersifat "segera". Artinya setiap unit organisasi akan melaksanakan setiap tugasnya dengan target sesegera mungkin, namun belum terdapat jangka waktu maksimal dalam penyelesaian tugas tersebut. Hal ini disebabkan keluhan pelanggan memiliki permasalahan dan solusi yang berbeda-beda, sehingga batas waktu maksimal yang diperlukan dalam menyelesaikan keluhan pun tidak dapat ditentukan secara pasti. Selain itu, jumlah pegawai bagian teknik yang bertugas dalam memperbaiki kerusakan teknis dilapangan dirasa masih terbatas, sehingga terkadang sulit untuk menyelesaikan banyak keluhan yang tersebar di beberapa lokasi pada dalam waktu satu hari, terutama jika terdapat kerusakan berat seperti memperbaiki kebocoran pipa distribusi yang berada di dalam jalan raya.

\section{Proposisi 3 :}

Batas waktu maksimal penanganan keluhan pelanggan yang memerlukan perbaikan teknis terkadang belum ditentukan, karena kecepatan penanganan dipengaruhi faktor penyebab dan solusi keluhan yang berbeda-beda, beserta faktor ketersediaan alat, barang maupun tenaga teknis yang memadai, sementara itu keluhan pelanggan lainnya dapat diselesaikan secara langsung oleh petugas Customer Service.

\section{d. Reaksi Atas Keluhan (Complaint Reaction)}

Pelanggan yang menyampaikan keluhan biasanya mengalami kerugian, sehingga sehingga perusahaan dapat memberikan kompensasi (Hansen et al, 2010) dengan menawarkan potongan harga, perbaikan, atau mengganti produk yang rusak, mengganti pengeluaran ekstra sang pelanggan, dll. Stauss dan Seidel (2010) menyatakan bahwa terdapat 3 jenis kompensasi dasar yang ditawarkan kepada pelanggan yang melakukan komplain, yaitu kompensasi finansial (dapat berupa uang ganti rugi atau diskon), kompensasi fisik (adanya perbaikan atau diganti dengan hal lain), dan kompensasi non fisik (berupa penjelasan atau permintaan maaf).

Hasil penelitian menunjukkan bahwa PDAM Tirta Satria telah memberikan kompensasi berupa kompensasi fisik (adanya perbaikan pada keluhan pelanggan yang berkaitan dengan masalah teknis seperti kebocoran pipa), dan kompensasi non fisik (berupa penjelasan solusi dan langkah perbaikan yang diambil untuk menyelesaikan berbagai contoh keluhan pelanggan seperti lonjakan tagihan, air keruh, kebocoran pipa, maupun air tidak mengalir) dalam penanganan keluhan pelanggan. Pegawai pun memberikan sikap yang ramah pada saat penanganan keluhan. Namun, persepsi pelanggan masih beragam atas reaksi tersebut. Beberapa pelanggan masih belum puas dengan kinerja pegawai yang 
dianggap masih lambat dalam menangani keluhan.

\section{Proposisi 4:}

Jika perbaikan teknis pada penanganan keluhan berjalan lambat maka dapat menimbulkan ketidakpuasan dalam diri pelanggan, meskipun kompensasi fisik, non fisik serta sikap ramah telah diberikan oleh lembaga penyedia layanan.

2. Proses Manajemen Keluhan Secara Tidak Langsung (Indirect Complaint Management Process)

Menurut Stauss dan Seidel (2010), "proses manajemen keluhan secara tidak langsung" merupakan proses dari tugas-tugas manajemen keluhan yang tidak melibatkan pelanggan, dan terdiri dari beberapa tahapan sebagai berikut.

a. Analisis Keluhan (Complaint Analysis)

Menurut Stauss dan Seidel (2010), keluhan mengandung petunjuk mengenai kelemahankelemahan suatu lembaga yang menyangkut perencanaan, produksi, pemasaran produk, serta menunjukkan hal-hal yang diinginkan oleh pelanggan atau peluang pasar, sehingga penting mengeksploitasi informasi-informasi tersebut secara sistematis baik melalui analisis kualitatif ataupun kuantitatif (seperti diagram Pareto). Pelaksanaan analisis kuantitatif PDAM Tirta Satria ditunjukkan dengan adanya tabel dan grafik Laporan Penanganan Keluhan Pelanggan Bulan Juni dan Juli 2017 (dapat dilihat pada tabel 3 dan gambar 2). Total keluhan pada bulan Juni dan Juli adalah 371 laporan, dengan keluhan terbanyak mengenai kebocoran. PDAM Tirta Satria pun menggunakan metode prioritas untuk menangani keluhan secara nomor urut, dan terkadang mendahulukan keluhan berat yang bersifat mendesak, seperti kebocoran pipa distribusi PDAM yang menyangkut kepentingan banyak (bisa menimbulkan aliran air mati di banyak pelanggan).

Tabel 3. Laporan Penanganan Pengaduan Pelanggan PDAM Tirta Satria Kabupaten Banyumas Pada Bulan Juni-Juli 2017

\begin{tabular}{llccc}
\hline \multirow{2}{*}{ No. } & \multirow{2}{*}{ Uraian } & \multicolumn{2}{c}{ Bulan } & \multirow{2}{*}{ Jumlah } \\
\cline { 3 - 4 } & & Juni & Juli & \\
\hline 1. & Angka Meter tidak sesuai & 0 & 0 & 0 \\
\hline 2. & Lonjakan pemakaian & 9 & 6 & 15 \\
\hline 3. & Bocor & 72 & 67 & 139 \\
\hline 4. & Air mati & 41 & 82 & 123 \\
\hline 5. & Air kecil tidak lancar & 18 & 29 & 47 \\
\hline 6. & Air keruh & 3 & 7 & 10 \\
\hline 7. & Meteran rusak & 7 & 5 & 12 \\
\hline 8. & Kerusakan Acc & 1 & 7 & 8 \\
\hline 9. & Pindah meter & 1 & 1 & 2 \\
\hline 10. & Galian pipa & 0 & 1 & 1 \\
\hline 11. & Lain-lain & 6 & 8 & 14 \\
\hline & Jumlah & 158 & 213 & 371 \\
\hline
\end{tabular}

Sumber: Dokumentasi PDAM Tirta Satria Kabupaten Banyumas 


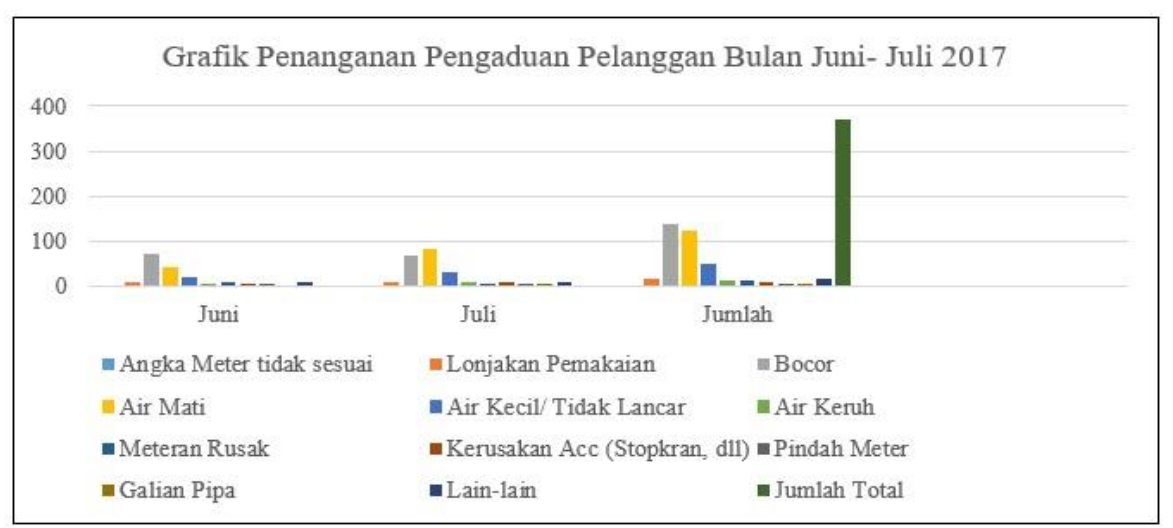

Gambar 2. Grafik Penanganan Pengaduan Pelanggan Bulan Juni- Juli 2017 Sumber : Dokumentasi PDAM Tirta Satria Kabupaten Banyumas

Dengan demikian, dapat disimpulkan bahwa PDAM Tirta Satria telah melaksanakan tahap analisis keluhan sesuai dengan teori Stauss dan Seidel, dengan memiliki analisis keluhan secara kuantitatif melalui tabel dan grafik yang rinci dan jelas mengenai Laporan Penanganan Keluhan Pelanggan Bulan Juni dan Juli 2017. Analisis keluhan tersebut dapat digunakan untuk mengetahui jumlah keluhan dan jenis keluhan yang paling tinggi setiap bulannya, sehingga dapat dijadikan pedoman untuk mengevaluasi kinerja.

\section{Proposisi 1:}

Apabila analisis kuantitatif keluhan pelanggan dilakukan secara berkala melalui grafik dan tabel, maka akan memudahkan lembaga penyedia layanan untuk mengetahui informasi jumlah dan jenis keluhan, yang dapat digunakan untuk mengevalulasi kinerja pelayanan.

b. Pengendalian Manajemen Keluhan (Complaint Management Controlling)

Pengendalian manajemen keluhan menurut Stauss dan Seidel (2010) dapat berhubungan dengan pengendalian tugas-tugas (tasks controlling), yaitu penentu dari indikator dan standar kualitas dari semua tugas-tugas manajemen keluhan. PDAM Tirta Satria pun memiliki standar kualitas yang wajib dipenuhi oleh para pegawai. Standar kualitas tersebut tercantum dalam motto pelayanan PDAM Tirta Satria yang berbunyi "Melayani air (Tirta) dengan Satria (Senyum, Antusias, Tertib, Ramah, Informatif, dan Amanah)".

Selain itu, menurut Stauss dan Seidel (2010) pengendalian kerja juga tugas-tugas secara subjektif (subjective tasks controlling) dapat dilakukan melalui survei kepuasan pelanggan. Sayangnya, PDAM Tirta Stria belum melakukan survei kepuasan pelanggan atas pelayanan pengaduan keluhan, sehingga belum tersedia kesempatan bagi pelanggan untuk menilai kinerja dan kualitas manajemen keluhan PDAM Tirta Satria berdasarkan persepsinya.

\section{Proposisi 2:}

Lembaga penyedia layanan memerlukan adanya survei kepuasan pelanggan atas penanganan keluhan untuk mengevaluasi kinerja manajemen keluhan. 
c. Pelaporan Keluhan (Complaint Reporting)

\begin{tabular}{lrr}
\multicolumn{2}{c}{ Pelaporan } & keluhan \\
merupakan informasi & yang \\
dikumpulkan & melalui & analisis
\end{tabular} keluhan dan pengendalian manajemen keluhan, dan harus tersedia bagi kelompok pelanggan internal seperti manajemen puncak, bagian pengendali kualitas, dan departemen pemasaran (Stauss dan Seidel (2010). PDAM Tirta Satria pun telah memiliki sistem pelaporan yang jelas dan baik kepada top management seperti Direksi dan Badan Pengawas PDAM Tirta Satria beserta Bupati Kabupaten Banyumas. Laporan ini dibuat setiap bulan, berupa analisis kuantitatif jumlah dan jenis keluhan pelanggan setiap bulannya, kemudian ditunjukkan melalui tabel 3 dan gambar 2 mengenai "Laporan Penanganan Pengaduan Pelanggan" PDAM Tirta Satria. Informasi keluhan pelanggan pun menjadi tersebar secara merata dan menyeluruh, sehingga memudahkan top management untuk menilai dan mengevaluasi kinerja penanganan keluhan PDAM Tirta Satria.

\section{Proposisi 3:}

Jika terdapat laporan keluhan yang lengkap dan berkala kepada top management, maka penyebaran informasi keluhan dalam manajemen keluhan berjalan baik dan memudahkan proses penilaian kinerja oleh top management.

d. Pemanfaatan Informasi Keluhan (Complaint Information Utilization)
Tujuan dari manajemen keluhan adalah untuk membuat kontribusi yang substansial terhadap kualitas manajamen dengan memanfaatkan informasi dari keluhan-keluhan yang telah didokumentasikan (Stauss dan Seidel, 2010). PDAM Tirta Satria pun telah melaksanakan pemanfaatan informasi keluhan dengan baik, yang ditunjukkan dengan adanya pandangan positif para pegawai terhadap keluhan pelanggan. Keluhan pelanggan dianggap bermanfaat bagi peningkatan kemajuan dan kualitas PDAM Tirta Satria, dan sebagai alat untuk menilai kinerja yang telah dicapai saat ini. Keluhan pelanggan juga memacu petugas selalu berusaha untuk selalu meningkatkan pelayanan dan kecepatan dalam penyelesaian keluhan pelanggan.

\section{Proposisi 4:}

Lembaga pelayanan publik dinilai baik apabila mau menerima dan menganggap posistif keluhan pelanggan, dan memanfaatkannya untuk meningkatkan kualitas dan kinerja pelayanan.

\section{Aspek-Aspek Manajemen}

\section{Keluhan PDAM Tirta Satria}

a. Aspek Sumber Daya Manusia

Sumber daya manusia merupakan salah satu faktor yang berpengaruh dalam pelaksanaan manajemen keluhan (Stauss dan Seidel, 2010). Sumber daya yang dimaksud adalah seluruh pegawai dari suatu lembaga ataupun organisasi penyedia layanan bagi pelanggan. Lovelock dan Wirtz (2011) menyatakan kesalahan 
yang paling umum dalam penanganan keluhan adalah Customer Service gagal untuk menunjukkan perilaku yang baik kepada pelanggan. Sikap yang perlu dimiliki oleh setiap pegawai dalam manajemen keluhan adalah memberikan feedback, juga ramah, sopan, dan gaya komunikasi yang baik (Stauss, 2002).

Sumber daya manusia di PDAM Tirta Satria terdiri dari pegawai Bagian Pelayanan seperti Customer Service dan Kasubbag Pelayanan, Kasubbag Umum, dan Bagian Teknik. Aspek sumber daya manusia yang menjadi faktor pendukung dalam manajemen keluhan adalah para pegawai memiliki sikap yang ramah, sopan, dan baik kepada pelanggan, dan berusaha untuk menerima serta menyelesaikan tugasnya dalam menangani keluhan dengan segera. Sementara itu, aspek sumber daya manusia yang menjadi faktor penghambat manajemen keluhan adalah pegawai teknik yang turun ke lapangan dirasa masih kurang jika dibandingkan dengan jumlah keluhan yang memerlukan perbaikan teknis setiap harinya, terutama jika terjadi perbaikan teknis yang memerlukan pengerjaan rumit dan waktu yang cukup lama, karena adanya perbaikan teknis keluhan dilakukan secara bergiliran dan memakan waktu yang kadang tidak bisa ditentukan.

b. Aspek Organisasional

Organisasi perlu mengidentifikasi nilai-nilai dan standar kinerja yang jelas bagi seluruh pegawai. Hal ini dapat diwujudkan dengan menetapkan visi dan misi organisasi, beserta standar perilaku pegawai dalam melaksanakan tugas (Cook dan Macaulay, 1997). PDAM Tirta Satria pun telah menetapkan nilainilai organisasi dalam memberikan pelayanan air melalui visi misi, dan motto pelayanan yang wajib dilaksanakan oleh para pegawai. Salah satu tantangan penanganan keluhan dalam suatu organisasi atau lembaga pelayanan publik adalah tidak menyadari keluhan pelanggan pada level strategis (Zairi, 2000). Keluhan dapat menjadi kesempatan kedua bagi organisasi atau lembaga pelayanan publik untuk mewujudkan kembali kepuasan pelanggan (Ogbeide, 2015). Para pegawai PDAM Tirta Satria menilai positif adanya keluhan pelanggan, dan menganggap keluhan pelanggan sebagai hal yang harus ditangani guna meningkatkan kualitas dan kinerja pelayanan air bersih PDAM Tirta Satria.

\section{Huppertz} menyatakan beberapa lembaga pelayanan menyediakan layanan penanganan keluhan dengan menyediakan buku keluhan ataupun layanan Call Center dan menyediakan media lain untuk melakukan keluhan. PDAM Tirta Satria menunjukkan usaha yang nyata dalam menstimulasi keluhan dengan menyediakan berbagai macam media yang dapat digunakan oleh pelanggan, seperti menerima keluhan langsung di 
bagian Customer Service yang berada dikantor PDAM Tirta Satria, melalui layanan Call Center pada (0281) 632324, ataupun melalui layanan kolom komentar di situs https://pdambanyumas.com.

PDAM Tirta Satria pun mengiklankan informasi tersebut melalui info di rekening tagihan pelanggan, di situs https://pdambanyumas.com., dan juga di kalender.

Davidow

menyebutkan bahwa dimensi organisasional manajemen keluhan adalah adanya fasilitas dan ketepatan waktu. PDAM Tirta Satria memiliki Standar Operasi Prosedur Penanganan keluhan yang berisikan tentang struktur, tugas, proses yang jelas mengenai penanganan keluhan pelanggan untuk pegawai Customer Service dan Kasubbag Pelayanan, Kasubbag Umum, dan Bagian Teknik. Namun, SOP ini belum menetapkan batas waktu yang pasti dari setiap penanganan keluhan, karena pertimbangan mengenai perbedaan jenis masalah, penyebab, dan solusi atas keluhan pelanggan, sehingga seringkali tidak bisa ditentukan waktu penyelesaiannya.

Stauss dan Seidel (2010) menyatakan bahwa terdapat 3 jenis kompensasi dasar yang ditawarkan kepada pelanggan yang melakukan komplain, yaitu kompensasi finansial (dapat berupa uang ganti rugi atau diskon), kompensasi fisik (adanya perbaikan atau diganti dengan hal lain), dan kompensasi non fisik (berupa penjelasan atau permintaan maaf). PDAM Tirta Satria memberikan kompensasi fisik seperti perbaikan teknis pada kerusakan saluran air yang bocor, serta memberikan kompensasi non fisik berupa perminaan maaf yang disertai penjelasan maupun solusi kepada pelanggan atas keluhan yang dihadapinya.

Stauss dan Seidel (2010) menyatakan pentingnya survei kepuasan pelanggan atas penanganan keluhan yang dialaminya, dan juga pelaporan keluhan kepada kelompok pelanggan internal seperti manajemen puncak, bagian pengendali kualitas, dan departemen pemasaran. PDAM Tirta Satria telah melaksanakan sistem pelaporan informasi keluhan secara berkala kepada top management namun belum melakukan survei kepuasan pelanggan atas penanganan keluhan yang dialaminya.

c. Aspek Teknologi Informasi

Cook dan Macaulay (1997) menjelaskan bahwa sistem informasi dan komunikasi harus bagus dalam memberdayakan manajemen keluhan. Zairi (2000) menyatakan bahwa salah satu cara untuk mengaudit efektivitas manajemen keluhan adalah dengan adanya penyebaran informasi kepada seluruh pegawai dalam mengeliminasi hal-hal penyebab keluhan pelanggan dan bisa memenuhi kebutuhan pelanggan dengan lebih baik. PDAM Tirta Satria telah 
menunjukkan penggunaan sistem pengaduan keluhan secara efektif dan efisien berbasis internet, dengan menyediakan kolom komentar di situs https://pdambanyumas.com sehingga memudahkan pelanggan untuk menyampaikan keluhan tanpa harus datang langsung ke kantor. Selain itu, sistem dokumentasi keluhan di PDAM Tirta Satria telah menggunakan sistem berbasis elektronik dan terintegrasi yang bernama SIKOMPAK. Proses pendokumentasian menjadi lebih cepat, dan memudahkan pegawai dalam mengolah maupun menganalisis secara kuantitatif keluhan pelanggan setiap bulannya, melalui data tabel dan grafik. Penyebaran informasi keluhan pun dapat dilakukan dengan cepat kepada seluruh unit organisasi yang berkaitan dalam penanganan keluhan.

\section{Penutup}

Berdasarkan hasil penelitian dan pembahasan, telah ditemukan empat proposisi pada proses manajemen keluhan secara langsung, sebagai berikut:

1. Beberapa pelanggan yang tidak menyadari informasi tentang beragam cara penyampaian keluhan, akan cenderung menggunakan satu jenis cara dalam menyampaikan keluhan.

2. Kemudahan akses penyampaian keluhan beserta sistem dokumentasi terintegrasi dan berbasis elektronik dapat mendukung kelancaran tahap penerimaan keluhan lembaga pelayanan publik.
3. Batas waktu maksimal penanganan keluhan pelanggan yang memerlukan perbaikan teknis terkadang belum ditentukan, karena kecepatan penanganan dipengaruhi faktor penyebab dan solusi keluhan yang berbeda-beda, beserta faktor ketersediaan alat, barang maupun tenaga teknis yang memadai, sementara itu keluhan pelanggan lainnya dapat diselesaikan secara langsung oleh petugas Customer Service.

4. Jika perbaikan teknis pada penanganan keluhan berjalan lambat maka dapat menimbulkan ketidakpuasan dalam diri pelanggan, meskipun kompensasi fisik, non fisik serta sikap ramah telah diberikan oleh lembaga penyedia layanan.

Selain itu, telah ditemukan pula empat proposisi pada proses manajemen keluhan secara tidak langsung, sebagai berikut:

1. Apabila analisis kuantitatif keluhan pelanggan dilakukan secara berkala melalui grafik dan tabel, maka akan memudahkan lembaga penyedia layanan untuk mengetahui informasi jumlah dan jenis keluhan, yang dapat digunakan untuk mengevalulasi kinerja pelayanan.

2. Lembaga penyedia layanan memerlukan adanya survei kepuasan pelanggan atas penanganan keluhan untuk mengevaluasi kinerja manajemen keluhan.

3. Jika terdapat laporan keluhan yang lengkap dan berkala kepada top management, maka penyebaran informasi keluhan dalam manajemen keluhan 
berjalan baik dan memudahkan proses penilaian kinerja oleh top management.

4. Lembaga pelayanan publik dinilai baik apabila mau menerima dan menganggapi posistif keluhan pelanggan, dan memanfaatkannya untuk meningkatkan kualitas dan kinerja pelayanan.

Kesimpulan yang dapat diambil adalah Manajemen keluhan PDAM Tirta Satria belum berjalan maksimal sesuai teori Stauss dan Seidel pada tahap stimulasi keluhan, karena sebagian pelanggan belum menyadari informasi kontak ataupun media lain dalam menyampaikan keluhan. Standar Operasi Prosedur Penanganan Keluhan PDAM Tirta Satria juga tidak memiliki batas waktu maksimal, sehingga tidak dapat memberikan kepastian waktu. PDAM Tirta Satria pun belum melaksanakan survei kepuasan pelanggan atas penanganan keluhan, sehingga belum dapat menilai kinerja penanganan keluhan berdasarkan persepsi pelanggan.

Aspek-aspek yang dapat mempengaruhi manajemen keluhan pelanggan PDAM Tirta Satria adalah aspek SDM, organisasional, dan teknologi informasi. Sikap pegawai yang ramah dan berupaya cepat dalam penanganan keluhan, beserta sistem pendokumentasian yang berbasis elektronik dan terintegerasi dapat memudahkan proses manajemen keluhan. Namun keterbatasan pegawai teknik yang turun ke lapangan kurang bisa menyeimbangi banyaknya jumlah keluhan kerusakan teknis setiap harinya, sehingga dapat berdampak pada penanganan keluhan yang lama dan beresiko penundaan penanganan keluhan lain hingga esok harinya.

PDAM Tirta Satria dapat meningkatkan kualitas manajamen keluhan dengan cara menginformasikan dan mengingatkan secara langsung kepada pelanggan mengenai kontak layanan Call Center yang tertera di rekening pada saat pelanggan membayar tagihan air. PDAM Tirta Satria dapat merumuskan batas waktu maksimal dalam penanganan keluhan agar dapat memberikan jaminan pelayanan kepada pelanggan, atau memberikan pengumuman dan konfirmasi ulang jika terjadi penundaan perbaikan teknis. PDAM Tirta Satria pun dapat menambah jumlah pegawai teknis jika ingin meningkatkan kecepatan perbaikan teknis dilapangan. Survei kepuasan pelanggan atas penanganan keluhan pun dapat dilakukan PDAM Tirta Satria untuk mengukur kinerja manajemen keluhan saat ini berdasarkan persepsi pelanggan.

\section{Daftar Pustaka}

Agus, Arawati. 2007. "An Exploratory Study of Service Quality in The Malaysian Public Service Sector". International Journal of Quality \& Reliability Management, Vol. 24 No. 2, 2007. pp. 177-190.

Akinboade, Oludele Akinloye, Emilie Chanceline Kinfack, and Mandisa Putuma Mokwena. 2012. "An Analysis of Citizen Satisfaction With Public Service Delivery In The Sedibeng District Municipality Of South Africa". International 
Journal of Social Economics, Vol. 39, Iss, pp. 182-199.

Alvarez, Leticia Suarez, Rodolfo Vazquez Casielles, and Ana Maria Diaz Martin. 2011. "Analysis of The Role Of Complaint Management In The Context Of Relationship Marketing". Journal of Marketing Management, Vol. 27, Nos. 1-2, pp. 143-164.

Berry, Riley, Sarah Tanford, Rhonda Montgomery, and Alison Green. 2014. "How We Complain: The Effect of Personality on Consumer Complaint Channel". Journal of Hospitality and Tourism Research, Vol. 42 Iss. 1.

Bosch, Veronica Gonzalez. 2005. "TQM and QFD: Exploiting A Customer Complaint Management System". International Journal of Quality \& Reliability Management, Vol. 22, No. 1, pp. 30-37.

Brennan, Carol and Alex Douglas. 2002. "Complaint Procedure in Local Government: Informing Your Customers". The Internasional Journal of Public Sector Management, Vol 15 No. 23, pp. 219-236.

Brewer, Brian. 2007. "Citizen Or Customer? Complaints Handling in The Public Sector". International Review of Administrative Sciences, Vol 73(4), pp. 549-556.

Cook, Sarah and Steve Macaulay. 1997. "Practical Steps Toempowered Complaint Management. Managing Service Quality, Vol. 7 No.1, pp. 39-42.
Davidow, Moshe. 2003.

"Organizational Responses to

Customer Complaints: What Works and What Doesn't". Journal of Service Research, Vol. 5 No. 3, pp. 225-250.

Filip, Alina. 2013. "Complaint Management: A Customer Satisfaction Learning Process". Procedia - Social and Behavioral Sciences 93, pp. 271-275.

Grainer, Marc, Charles H. Noble, Mary Jo Bitner and Scott M. Broetzmann. 2014. "What Unhappy Customers Want". MIT Sloan Management Review Spring, Vol. 55 No. 3.

Hansen, Torben, Ricky Wilke, Judith Zaichkowsky. 2010. "Managing Consumer Complaints: Differences and Similarities Among Heterogeneous Retailers". International Journal of Retail \& Distribution Management, Vol. 38 Iss 1, pp. 6-23

Hsiao, Yu-Hsiang, Li-Fei Chen, Yoon Leng Choy, and ChaoTon Su. 2016. "A Novel Framework for Customer Complaint Management". The Service Industries Journal

Huppertz, John W. 2007. "Firms' Complaint Handling Policies and Consumer Complaint Voicing." Journal of Consumer Marketing, Vol. 24 Iss 7, pp. 428-437.

John, Peter. 2016. "Finding Exits and Voices: Albert Hirschman's Contribution to the Study of Public Service". International Public Management Journal, pp. 1-18. 
Lovelock, Christoper and Jochen Wirtz. 2011. Service Marketing: People, Technology, Strategy, 7th Edition.

Miles, Matthew B., A. Michael Huberman, and Johnny Saldaña. 2014. Qualitative Data Analysis: A Methods Book 3rd Edition. Thousand Oaks, CA: Sage Publication.

Nimako, Simon Gyasi Mr. 2012. "Customer Dissatisfaction and Complaining Responses Towards Mobile Telephony Services," The African Journal of Information Systems, Vol. 4: Iss. 3, Article 1.

Ogbeide, Godwin Charles A, Stefanie Boser, and Robert J Harrinton. 2015. "Complaint Management in Hospitality Organizations: The Role Of Empowerment And Other Service Recovery Attributes Impacting Loyalty And Satisfaction". Tourism and Hospitality Research, pp. 1-13.

Ryngelblum, Arnaldo L. 2013. "The

Ways Companies Really Answer Consumer Complaints". Marketing Intelligence \& Planning, Vol. 31 Iss 1, pp. 54-71.

Stauss, Bernd. 2002. "The Dimensions of Complaint Satisfaction: Process and Outcome Complaint Satisfaction Versus Cold Fact and Warm Act Complaint Satisfaction", Managing Service Quality: An International Journal, Vol. 12 Iss 3 pp. 173-183

Stauss, Bernd and Wolfgang Seidel. 2010. "Complaint
Management: The Heart of CRM". In: Gavriel Salvendy and Waldemar Karwowski (Eds), Introduction to Service Engineering, pp. 414-432.

Taleghani, Mohammad, Mahmood Samadi Largani, Shahram Gilaninia, and Seyyed Javad Mousavian. 2011. "The Role of Customer Complaints Management in Consumers Satisfaction for New Industrial Enterprises of Iran". International Journal of Business Administration, Vol. 2, No. 3.

Tojib, Dewi and Saman Khajehzadeh. 2014. "The role of meta-perceptions in customer complaining behavior". European Journal of Marketing, Vol. 48, Iss 7/8, pp. 1536-1556.

Tronvoll, Bard. 2011. "Negative Emotions and Their Effect on Customer Complaint Behaviour". Journal of Service Management, 22(1), pp. 111-134.

Vos, J. F. J. G. B. Huitema, and E. de Lange-Ros. 2008. "How Organisations Can Learn from Complaints". The TQM Journal, Vol. 20 No. 1, pp. 817.

Vuk, T. 2013. "Management of Complaints and Product Recall". International Society of Blood Transfusion, ISBT Science Series, 8, pp. 33-36

Walle, Steven Van de. 2016. "When Public Services Fail: A Research Agenda on Public Service Failure". Journal of Service Management, Vol. 27 Iss 5. 
Zairi, Mohamed. 2000. "Managing

Customer Dissatisfaction

Through Effective Complaints

Management Systems". The TQM Magazine, Vol. 12 Iss 5, pp. 331-337 